\title{
Unmasking the Anti-La/SSB Response in Sera From Patients With Sjogren's Syndrome by Specific Blocking of Anti-idiotypic Antibodies to La/SSB Antigenic Determinants
}

\author{
John G. Routsias, ${ }^{1}$ Evgenia Touloupi, ${ }^{1}$ Eleni Dotsika, ${ }^{2}$ Avrilia Moulia, ${ }^{3}$ Vassilios Tsikaris, ${ }^{2}$ Constantinos \\ Sakarellos, ${ }^{3}$ Maria Sakarellos-Daitsiotis, ${ }^{3}$ Haralampos M. Moutsopoulos, ${ }^{1}$ Athanasios G. Tzioufas ${ }^{1}$ \\ ${ }^{1}$ Department of Pathophysiology, School of Medicine, National University of Athens \\ ${ }^{2}$ Hellenic Pasteur Institute, Athens, Greece \\ ${ }^{3}$ Department of Organic Chemistry and Biochemistry, School of Physical Sciences, University of Ioannina, \\ Ioannina, Greece \\ Communicated by A.G. Papavassiliou. Accepted May 15, 2002
}

\begin{abstract}
Background: Autoantigen La/SSB is molecular target of humoral autoimmunity in patients with primary Sjogren's Syndrome (pSS) and systemic lupus erythematosus (SLE). In this study, we investigated the existence and possible influence of anti-idiotypic response to anti-La/SSB antibodies. Materials and Methods: Synthetic peptide analogs (pep) of the major antigenic determinants of La/SSB (289-308aa and 349-364aa) were prepared. Based on "molecular recognition" theory, complementary peptides (cpep), derived by anti-parallel readings of the noncoding strand of La/SSB DNA encoding for its antigenic determinants, were constructed. Sera from 150 patients with anti-La/SSB antibodies, 30 patients without anti-La/SSB antibodies, and 42 normal individuals were tested against all four peptides. $\mathrm{F}\left(\mathrm{ab}^{\prime}\right)_{2}$ fragments from anti-peptide IgG were prepared and $F\left(a b^{\prime}\right)_{2}$ - IgG interactions were evaluated using a specific anti-idiotypic ELISA.

Results: All four peptides were recognized by anti-La positive sera $(83 \%$ and $51 \%$ for pep and cpep $349-364$ and $51 \%$ and $28 \%$ for pep and cpep289-308, respectively). Anti-cpep $\mathrm{F}\left(\mathrm{ab}^{\prime}\right)_{2}$ bound to a common idiotype (Id) located
\end{abstract}

within or spatially close to the antigen combining site of anti La/SSB (anti-pep) antibodies. Homologous and crossinhibition experiments further confirmed this relation. The anti-idiotypic antibodies inhibited the anti-La/SSB antibody binding to recombinant La/SSB by $91 \%$. To overcome the anti-idiotypic interference in anti-La/SSB detection, a specific assay was developed. Sera were heated for dissociation of Id-anti-Id complexes, anti-Id antibodies blocked with cpep, and anti-La/SSB reactivity was recovered. Application of this method to anti-Ro positive-anti-La/SSB "negative" sera showed that all anti-Ro/SSA positive autoimmune sera also possess anti-La/SSB antibodies. This reaction was not observed in 14 anti-Ro negative- antiSm/RNP positive sera from patients with SLE.

Conclusions: Autoimmune sera from patients with pSS and SLE contain anti-idiotypic antibodies targeting a common anti-La/SSB idiotype. These antibodies can be detected using complementary peptides of La/SSB epitopes. The antiidiotypic antibodies mask the anti-La/SSB response. Hidden anti-La/SSB antibodies can be released and detected using complementary epitope analogs.

\section{Introduction}

Molecular targets of humoral autoimmunity in patients with primary Sjogren's syndrome (pSS) and systemic lupus erythematosus (SLE) are clustered in subcellular ribonucleoprotein particles called La/Ro RNP complexes $(1,2)$. Recent evidence suggests that an autoantibody response to La/Ro RNPs is antigen driven and involves a number of $\mathrm{B}$ - and T-cell epitopes within the protein components of these complexes $(3,4)$.

We previously mapped the location of B-cell antigenic determinants in both Ro/SSA $60-\mathrm{kD}$ and La/SSB 48-kD autoantigens (5,6, reviewed in 7) and

Correspondence and reprint requests should be addressed to: A. G. Tzioufas MD, Dept. of Pathophysiology, National University of Athens, School of Medicine, 75, Mikras Asias St., 11527 Athens, Greece. Phone: +3017771095; fax: +3017703876; e-mail: agtzi@med.uoa.gr have shown molecular spreading of epitopes to La/Ro RNP after immunization with a single antigenic peptide (8). These data are consistent with a number of studies reporting intra- and inter-molecular spreading to La/Ro RNP (reviewed in 3). The diversification of a B-cell response requires the delivery of T-cell help from autoreactive T-cells. T-cell determinants have been recently mapped in the La/SSB protein (8-10).

Anti-idiotypic (anti-Id) antibodies reactive with idiotypes (Id) of autoantibodies or autoreactive clonotypic T-cells are capable of regulating the autoimmune response $(11,12)$. In this report we sought to study the Id- anti-Id network in anti-La/SSB positive sera, exploiting the complementary peptide approach to overcome the unavailability of sequence data from $\mathrm{V}$ regions of idiotypic antibodies or clonotypic $\mathrm{T}$ cells. According to this procedure, translation of two complementary RNA strands into protein generates a pair 
of peptides that bind each other with specific and high affinity $(13,14)$. A large body of experimental work (15-23) supports this theory. Thus, when sense peptide resembles a B-cell epitope, a T-cell determinant, or a specific ligand, the antisense (complementary) peptide can induce the formation of antibodies with anti-idiotypic $(16-18)$, anti-TCR $(19,20)$, or antireceptor (21-23) specificity, respectively.

To test this hypothesis, we synthesized peptides deduced from the antisense RNA, corresponding to one immunodominant T-cell/minor B-cell epitope (cpep 289-308) and one subdominant T-cell/major B-cell epitope (cpep 349-364) of La/SSB autoantigen $(8-10,24)$. These peptides have been assayed for their ability to recognize anti-Id Ab in autoimmune sera. Based on this property, complementary peptides were found capable of unmasking specific antiLa/SSB autoantibodies.

\section{Material and Methods}

\section{Human Sera}

Sera from patients with pSS and SLE were screened for anti-La/SSB reactivity by counterimmunoeloctrophoresis (CIE) as previously described (6). One hundred fifty anti-La/SSB positive sera (110 from patients with SS and 40 from patients with SLE) were used for the detection of anti-peptide antibodies. All patients fulfilled the diagnostic criteria for pSS (25) and SLE (26). Thirty anti-La/SSB and antiRo/SSA negative sera from patients with pSS and SLE, as well as 42 sera from healthy blood donors served as disease and normal controls, respectively.

For the detection of masked anti-La/SSB antibodies, anti-Ro(SSA)/ANA positive-anti-La/SSB negative sera from 19 patients with SS, 25 patients with SLE and 7 normal individuals were utilized.

\section{Peptide Synthesis and Purification}

The two La/SSB B-cell/T-cell epitopes $\mathrm{A}^{289} \mathrm{NNGN-}$ LQLRNKEVTWEVLEG ${ }^{308}$ (pep2890308) and $\mathrm{G}^{349}$. SGKGKVQFQGKKTKF $^{364}$ (pep349-364) as well as their complementary peptides $\mathrm{S}^{308}$ FEYFPSHFFVPELEVTIIC $^{289}$ (cpep289-308) and $\mathrm{K}^{364}$ FRFLALKLYFSFTRP $^{349}$ (cpep349-364) were synthesized by the stepwise solid phase procedure (SPPS) in their amide forms on benzydrylamin resin according to standard methods (27).

A new helical carrier for multiple anchoring of antigenic peptides incorporating an $\alpha$-aminoisobutyric residue in each repetitive moiety, Ac-(Lys-Aib-Gly) ${ }_{n}$, $\left(\mathrm{SOC}_{\mathrm{n}}\right)$ was applied in this study, for anchoring the epitopes by the Lys- $\varepsilon \mathrm{NH}_{2}$ groups $(28,29)$. Sense and antisense La/SSB peptide epitopes were attached in four copies and two copies each, respectively, to the new tetrameric carrier, $\mathrm{SOC}_{4}$, and used for immunizations and ELISA experiments. An irrelevant $\mathrm{SOC}_{4}{ }^{-}$ peptide sequence [(IASRYDQL $)_{4}$-SOC, corresponding to the sequence 250-257aa of Leismania gp63] was also constructed and used as a control peptide.
The La/SSB synthetic epitopes pep289-308 and pep349-364 were also synthesized in the biotinylated amide forms. Biotinylation was performed after the addition of a four amino acid spacer (-GlySer-Gly-Ser-) as previously described (24).

All peptides were purified by high performance liquid chromatography (HPLC) and subjected to amino acid analysis and mass spectroscopy (MS) that confirmed their purity and identity.

\section{La/SSB Recombinant Protein}

$\mathrm{La}$ /SSB recombinant protein was prepared from a La/SSB cDNA as previously described (30) and purified by poly(U)-Sepharose affinity chromatography (31).

\section{Isolation of anti-peptide IgG}

Specific immunoaffinity columns of $\mathrm{CNBr}$ activated sepharose $4 \mathrm{~B}$ were generated by standard methods, using $20 \mathrm{mg}$ of each synthetic peptide, in its $\mathrm{SOC}_{4}$ form.

IgG from five sera that strongly recognized the La/SSB epitopes in ELISA were purified by proteinA sepharose, concentrated, dialyzed against PBS, and passed through the peptide immunoaffinity columns. Each column was washed with PBS and eluted with urea $8 \mathrm{M}$. The eluates were dialyzed against PBS, concentrated, and redialyzed. Anti-peptide IgG concentrations were evaluated by Lowry assay (DC Protein Assay, Biorad, USA).

\section{Preparation of $\mathrm{F}\left(a b^{\prime}\right)_{2}$ Anti-peptide Fragments}

Purified IgG, from sera with strong anti-peptide activity, were subjected to enzymatic degradation with pepsin. Briefly, IgG fractions were concentrated to $10 \mathrm{mg} / \mathrm{ml}$ and preincubated in $0.1 \mathrm{M} \mathrm{Na}$-acetate buffer $(\mathrm{pH}=4.5)$ for $5 \mathrm{hr}$ to increase its enzymatic susceptibility to digestion (32). Degradation of IgG was performed by the addition of pepsin (SIGMA Chemical Co, St. Louis MO, USA) at enzyme:protein ratio of $3 \%(\mathrm{w} / \mathrm{w})$ and incubation at $37^{\circ} \mathrm{C}$ overnight. The enzymatic reaction was stopped by adding pepstatin and raising the $\mathrm{pH}$ to 8.0 with $0.1 \mathrm{M} \mathrm{NaOH}$. Undigested IgG molecules were less than $2 \%$ and removed by passage through protein-A sepharose. The $\mathrm{F}\left(\mathrm{ab} \mathrm{b}_{2}\right)_{2}$ preparations were concentrated and dialyzed against PBS. Protein-A eluate was found to contain all the undigested material $(100 \%)$ and approximately $15 \%$ of the $F\left(a^{\prime}\right)_{2}$ fragment, in agreement with previous studies (33). The final product was free of traces of intact IgG (Fig. 1).

Anti-peptide specific $\mathrm{F}\left(\mathrm{ab}^{\prime}\right)_{2}$ fragments were isolated by immunoaffinity chromatography with peptide-affinity columns, using the procedure described for undigested IgG.

The efficiency of the enzymatic digestion was examined by Western blotting (34). The samples were applied to polyacrylamide gel sodium dodecyl sulfate (SDS) electrophoresis using nonreducing conditions, followed by electrotransfer to nitrocellulose and staining with Ponseu S. 


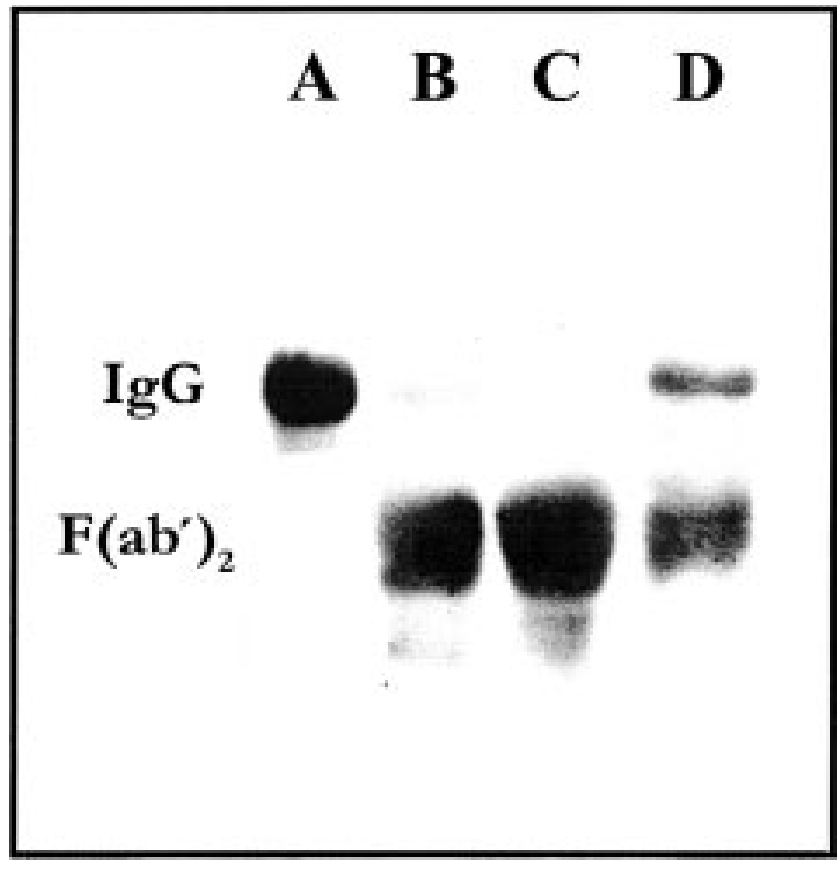

Fig. 1. Western blot, showing peptic digestion of purified IgG. (A) Undigested IgG. (B) Digested IgG with pepsin for $12 \mathrm{hr}$ at $37^{\circ} \mathrm{C}$. (C) Digested IgG after passage through protein-A column. (D) Eluate from protein-A column.

\section{Cell Extract and Immunoblotting}

Cytoplasmic extract from HeLa cells was prepared by standard methods. The samples of extracts were applied to SDS-PAGE under reducing conditions, followed by transfer to nitrocellulose. The nitrocellulose blots were cut into strips that were blocked with nonfat milk $5 \%$ and incubated with purified anti-peptide antibodies at $4^{\circ} \mathrm{C}$ overnight. Afterward, anti-human IgG conjugated to horseradish peroxidase was added and allowed to react for $1 \mathrm{hr}$. The color was developed by adding a substrate solution of 4-chloro-l-napthol to the strips.

\section{Assays for Anti-peptide and Anti-Id Antibodies}

1. Anti-peptide antibodies were detected by a modified ELISA assay (35), optimized for each different synthetic peptide analog. COSTAR high binding microtitre plates were coated overnight at $4^{\circ} \mathrm{C}$ with $100 \mu$ l of the appropriate $\mathrm{SOC}_{n}{ }^{-}$ peptide solution: pep289-308 (10 $\mu \mathrm{g} / \mathrm{ml}$ in carbonate/bicarbonate buffer $\mathrm{pH}=9.1$ ) or cpep289$308(10 \mu \mathrm{g} / \mathrm{ml}$ in carbonate/bicarbonate buffer $\mathrm{pH}=9.1)$ or pep349-364 $(5 \mu \mathrm{g} / \mathrm{ml}$ in phosphate buffer $\mathrm{pH}=7.1)$ or cpep349-364 $(10 \mu \mathrm{g} / \mathrm{ml}$ in phosphate buffer $\mathrm{pH}=7.1)$. After blocking the remaining binding sites with blocking buffer (BB:2\% BSA, $0.1 \%$ Tween20 in PBS) for $1 \mathrm{hr}$ at room temperature and washing with PBS $-0.05 \%$ Tween20, the plates were incubated overnight at $4^{\circ} \mathrm{C}$ with the appropriate material: patient sera $(1: 100$ in $\mathrm{BB})$ or purified IgG $(10 \mu \mathrm{g} / \mathrm{ml}$ in $\mathrm{BB})$ or purified $\mathrm{F}\left(\mathrm{ab}^{\prime}\right)_{2}(5 \mu \mathrm{g} / \mathrm{ml}$ in $\mathrm{BB})$. The wells were then washed and goat anti-human IgG conjugated to alkaline phosphatase (1:3000 in BB) was added. Subsequently, the plates incubated for $\mathrm{lhr}$ at room temperature followed by washing and addition of $100 \mu \mathrm{l}$ p-nitrophenol substrate at $37^{\circ} \mathrm{C}$. Absorbance of the color was measured at $405 \mathrm{~nm}$ after $20 \mathrm{~min}$.

2. Anti-Id activity of purified antibodies was also evaluated by ELISA. Costar microtitre plates were coated with each specific anti-peptide $F\left(a b^{\prime}\right)_{2}$ fragment at a concentration of $5 \mu \mathrm{g} / \mathrm{ml}$ in carbonate-bicarbonate buffer, $\mathrm{pH}=$ 9.6. After an overnight incubation the plates were blocked, washed and incubated with each specific antipeptide IgG $(10 \mu \mathrm{g} / \mathrm{ml}$ in $\mathrm{BB})$ overnight at $4^{\circ} \mathrm{C}$. The wells then were washed, and goat anti-human IgG (Fc specific 1:3000 in BB) was added. Following $1 \mathrm{hr}$ incubation and washing, p-nitrophenol substrate was added, and color development was read as previously.

\section{Inhibition Assays}

1. Homologous inhibition of anti-Id antibodies. The specificity of the binding of anti-pep IgG to anti-cpep $F\left(a b^{\prime}\right)_{2}$ and anti-cpep IgG to anti-pep $\mathrm{F}\left(\mathrm{ab}^{\prime}\right)_{2}$ was ascertained by homologous inhibition using known amounts of individual $\mathrm{F}\left(\mathrm{ab}^{\prime}\right)_{2}$ as inhibitors. Briefly, increasing concentrations $(0-30 \mu \mathrm{g} / \mathrm{ml})$ of $\mathrm{F}\left(\mathrm{ab}^{\prime}\right)_{2}$ were mixed with the specific IgG and the mixture incubated for $2 \mathrm{hr}$ at room temperature before its application in wells coated with $\mathrm{F}\left(\mathrm{ab}^{\prime}\right)_{2}$. The procedure continued as described above in the idiotype binding assay section.

2. Competitive inhibition of anti-Id antibodies binding to the antigen combining site. The paratope-idiotype relationship of anti-pep and anti-cpep antibodies, respectively, was characterized by two types of competitive ELISA assays as follows: (i) In the first, Id-bearing anti-pep 289-308 or anti-pep349$364 \mathrm{~F}\left(\mathrm{ab}^{\prime}\right)_{2}$ fragments were attached to microtiter plates. Anti-cpep289-308 or anti-cpep349-364 anti-Id IgG were applied in the wells directly or after prior incubation for $2 \mathrm{hr}$ at $25^{\circ} \mathrm{C}$ with increasing concentrations $(0-20 \mu \mathrm{g} / \mathrm{ml})$ of cpep289308 or cpep349-364 $\mathrm{SOC}_{2}$ peptide respectively. (ii) In the second assay, anti-Id anti-cpep289-308 or anti-cpep349-364 $\mathrm{F}\left(\mathrm{ab}^{\prime}\right)_{2}$ fragments (anti-Id) were immobilized in microtiter plates. Id-bearing anti-pep289-308 or anti-pep349-364 IgG were coincubated, for $2 \mathrm{hr}$ at room temperature, with known amounts of the counter peptides pep289308 or cpep349-364, respectively and applied to the wells. This was then followed by an ELISA assay, as previously described.

3. Inhibition of Id binding to La/SSB by anti-Id antibodies. Antigen-combining site associated Id determinants of anti-pep antibodies were also sought by the ability of anti-Id (anti-cpep) IgG to inhibit 
the binding of anti-pep antibodies to La/SSB coated plates. Ninety-six-well flat-bottomed plates (Costar) were coated with purified recombinant $\mathrm{La} / \mathrm{SSB}$ antigen at $5 \mu \mathrm{g} / \mathrm{ml}$ in carbonate-bicarbonate buffer $(\mathrm{pH}=9.6)$ at $4^{\circ} \mathrm{C}$ overnight. Excess binding sites were then blocked for $1 \mathrm{~h}$ at $25^{\circ} \mathrm{C}$ with $2 \%$ BSA in PBS. After washing, wells were incubated overnight at $4^{\circ} \mathrm{C}$ for $1 \mathrm{hr}$ at $25^{\circ} \mathrm{C}$ with mixtures, containing $2.5 \mu \mathrm{g} / \mathrm{ml}$ of specific antipep IgG and varying amounts of the corresponding anti-cpep IgG $(0-40 \mu \mathrm{g} / \mathrm{ml})$. The procedure was then continued as described above for antipeptide ELISA.

4. Inhibition of paratope-epitope binding by sense-antisense peptide interactions. The ability of La/SSB synthetic epitope analog to associate with their complementary counterparts was assessed by an inhibition ELISA. Briefly, $100 \mu \mathrm{l}$ of anti-pep IgG coated in 96-well high binding plates at $0.5 \mu \mathrm{g} / \mathrm{ml}$ in carbonate buffer $(\mathrm{pH}=9.6)$. Coating was carried out at $4{ }^{\circ} \mathrm{C}$ overnight and followed by blocking with $2 \%$ BSA in PBS. Biotinylated peptide pep289308 or pep349-364 in their amide forms, were pre-incubated at $30 \mu \mathrm{g} / \mathrm{ml}$ with amounts varying from $0-250 \mu \mathrm{g} / \mathrm{ml}$ of cpep289-308 or cpep349364, respectively, and added in the wells. After washing, $100 \mu \mathrm{l}$ of 1:1500 streptavidin-peroxidase conjugate was added and incubated at room temperature for $1 \mathrm{hr}$. The color was developed with 2'-azino-cis-3-ethybenzotriazoline sulfonic acid (ABTS) and measured at $405 \mathrm{~nm}$.

\section{Results}

\section{Design and Predicted Features of the La/SSB}

Epitope Complementary Peptide Analogs

We initially investigated whether the epitopes of La/ SSB and their complementary peptide analogs possess hydropathically complementary properties as suggested from the molecular recognition theory (13-15).

Using the human La/SSB nucleotide sequence data (Swiss-Prot AccNumber P05455), complementary peptides for the two La/SSB epitopes were designed. The amino acid sequences of cpep289-308 and cpep349-364 free peptides, were derived by 5' to $3^{\prime}$ assignment of amino acids to nucleotide sequences complementary to the mRNA of La/SSB protein encoding regions $289-308$ and 349-364, respectively (Fig. 2A). The complemetary mRNA for cpep289-308 included three stop codons (positions 3, 13, and 15). Glutamic acid was placed in these positions because its hydropathic score $(-3.5)$ is complementary to that of the corresponding leucine residues in sense peptide (+3.7) (36).

According to the hydrophobicity plot, based on Fauchere/Pliska (37) and Goldman/Engelman/Steitz (GES) (38) scales, both complementary peptides cpep289-308 and cpep349-364 presented inverted hydrophobicity profile compared with the peptides pep289-308 and pep349-364 (Fig. 2B).
Specific Recognition of Complementary

Peptides from Autoimmune Sera

Human autoimmune sera from patients with SLE or SS were screened in ELISA to investigate the prevalence of anti-pep and anti-cpep antibodies (Fig. 3A-D). The La/SSB epitope analogs pep289-308 and pep349-364 (in their $\mathrm{SOC}_{4}$ forms) were recognized by $51 \%$ and $83 \%$ of anti-La/SSB positive sera, respectively, whereas antibodies to their complementary peptides, cpep289-308 and cpep349-364, were detected in $28 \%$ and $51 \%$ of sera with antiLa/SSB reactivity. Disease control autoimmune sera, negative for anti-La/SSB and anti-Ro/SSA antibodies, showed no reaction with pep349-364, and cpep349-364, and a limited reaction with peptides pep289-308 (3\%) and cpep289-308 (7\%). Normal sera used in all ELISA tests were negative for antipeptide antibodies with the exception of one normal serum, which gave a marginally positive reaction with peptide cpep349-364. The existence of antibodies in patients sera, capable of recognizing the lysine substituted backbone, was excluded by the use of the irrelevant SOC-peptide sequence [(IASRYDQL) $)_{4}$-SOC] as a control peptide. None of the sera tested gave a positive reaction with the control peptide (data not shown).

To evaluate the association of anti-pep and anticpep antibodies, 30 sera with high antibody binding levels in pep289-308 or cpep289-308 and 40 sera that exhibited high anti-pep349-364 or anti-cpep349-364 reactivity were tested. All anti-La/SSB positive sera containing antibodies against the complementary peptides cpep289-308 and cpep349-364 also had antibodies to pep289-308 and pep349-364 respectively. On the other hand, one third of anti-La/SSB sera, positive for antibodies against the epitope peptide analogs (anti-pep positive sera), were found to be negative for anti-cpep antibodies (data not shown).

\section{Purified Anti-complementary Peptide Antibodies Possess Anti-Id Activity}

Specific anti-pep and anti-cpep IgG and $F\left(a^{\prime}\right)_{2}$ fragments were isolated and prepared from five sera with strong reactivity. The purified antibodies and $\mathrm{F}\left(\mathrm{ab}^{\prime}\right)_{2}$ fragments were found to recognize specifically the peptide against which they were purified (data not shown). Purified antibodies to pep289-308 and pep349-364 as well as their $\mathrm{F}\left(\mathrm{ab}^{\prime}\right)_{2}$ fragments exhibited high anti-La/SSB activity against recombinant La/SSB in ELISA and immunoblot, and they gave also a positive speckled nuclear immunofluorescence staining in an adjusted titer 1:1280 on Hep2 cells (data not shown).

To evaluate the Id-anti-Id relationship of purified antibodies, an indirect binding assay was utilized. Therefore, isolated anti-pep or anti-cpep $\mathrm{F}\left(\mathrm{ab}^{\prime}\right)_{2}$ fragments were incubated with intact IgG of anti-cpep or anti-pep specificity, respectively and 
A

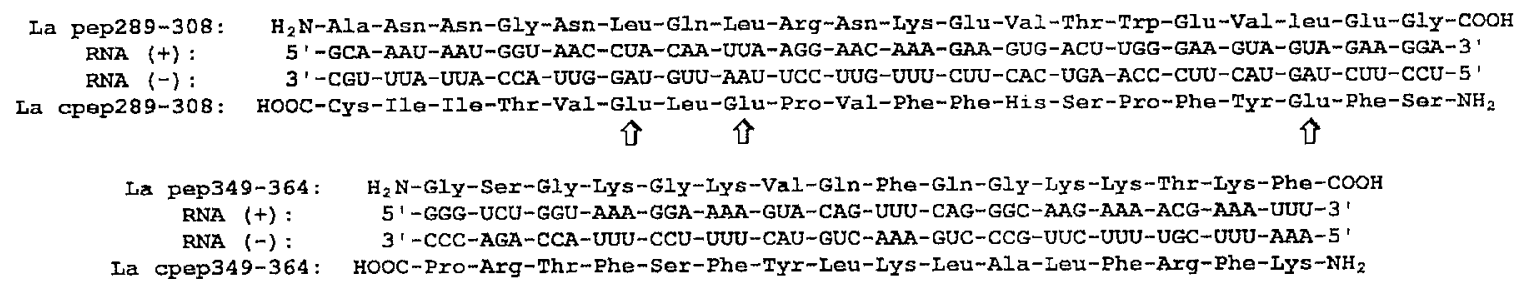

La cpep289-308: HooC-Cys-Ile-Ile-Thr-VaI-Glu-Leu-Glu-Pro-Va1-Phe-Phe-His-Ser-Pro-Phe-Tyr-Glu-Phe-Ser-NH

$\mathrm{H}_{2} \mathrm{~N}-\mathrm{Al} \mathrm{a}-\mathrm{Asn}-\mathrm{Asn}-\mathrm{GlY}-\mathrm{Asn}-\mathrm{Leu}-\mathrm{Gln}-\mathrm{Leu}-\mathrm{Arg}$-Asn-LYs -Glu-VaI-Thr-Trp-Glu-Val-1eu-GIu-GlY-COOH

5 ' -GCA-AAU-AAU-GGU-AAC-CUA-CAA-UUA-AGG-AAC-AAA-GAA-GUG-ACU-UGG-GAA-GUA-GUA-GAA-GGA-3

3 ' -CGU-UUA-UUA-CCA-UUG-GAU-GUU-AAU-UCC-UUG-UUU-CUU-CAC-UGA-ACG-CUU-CAU-GAU-CUU-CCU-5' ษ

B
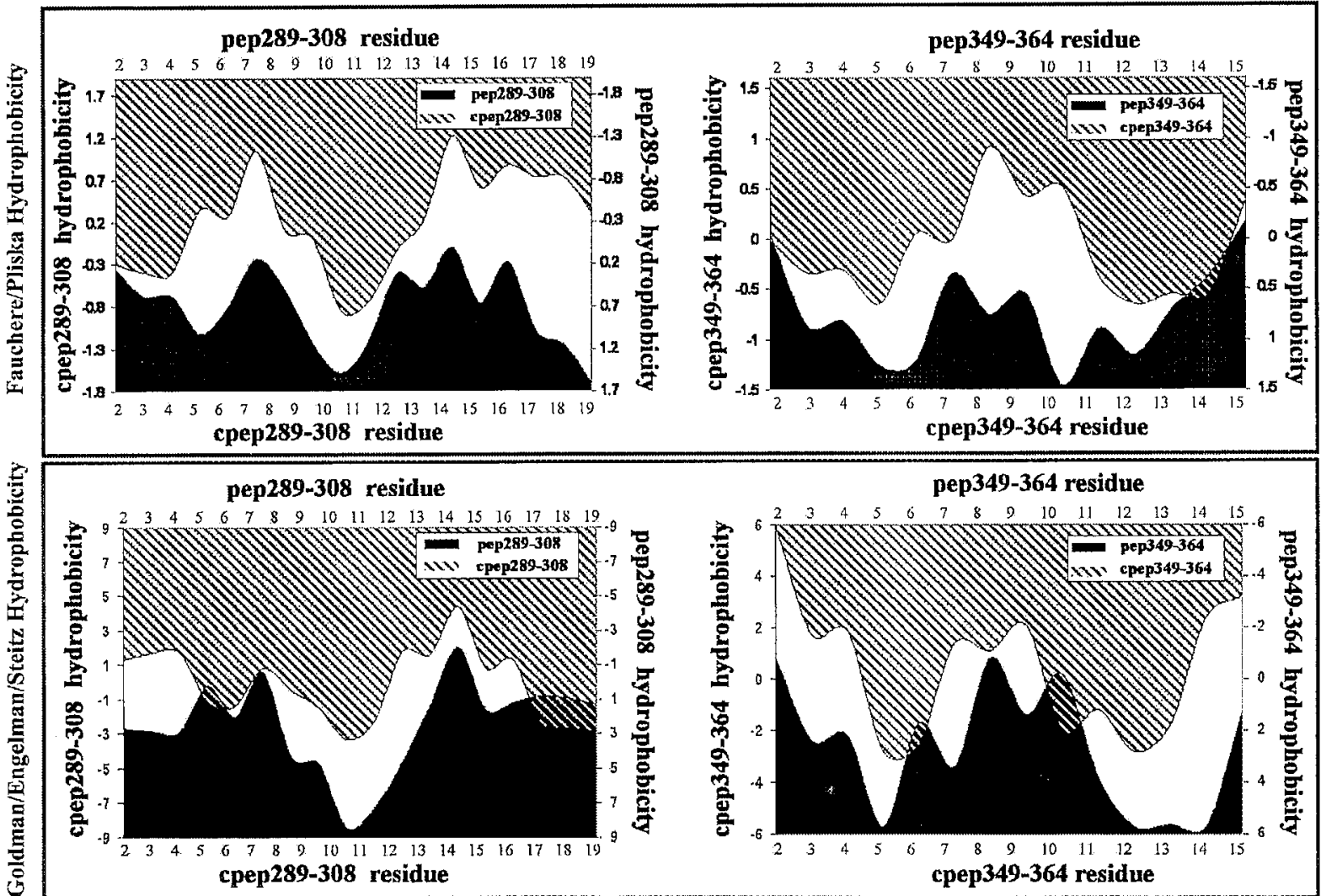

Fig. 2. (A) Design of the complementary peptides using the antisense approach. Codons in the complementary RNA [RNA(-)] were assigned in the $5^{\prime}$ to $3^{\prime}$ direction to derive the amino acid sequence of complementary peptides. Arrows indicate the positions of stop codons in cpep289-308 RNA(-) sequence. Glutamic acid was placed in these positions as it has complementary hydropathy to the corresponding leucine in RNA(+) sequence. (B) Sense and antisense peptides possess complementary hydrophobicity profiles according to Fauchere/Pliska (37) and GES (38) scales.

anti-Id reaction was detected with a second antibody to the Fc portion of IgG. Both anti-pep289-308 and anti-pep349-364 $\mathrm{F}\left(\mathrm{ab}^{\prime}\right)_{2}$ fragments bind specifically to antibodies against their complementary peptides, cpep289-308 and cpep349-364. In a similar way, $\mathrm{F}\left(\mathrm{ab}^{\prime}\right)_{2}$ fragments against complementary peptides cpep289-308 and cpep349-364 were recognized by anti-pep289-308 and anti-pep349-364 IgG, respectively (Fig. 4). None of the anti-pep and anti-cpep $\mathrm{F}\left(\mathrm{ab}^{\prime}\right)_{2}$ fragments reacted with normal IgG. The specificity of anti-Id assays and the purity of $\mathrm{F}\left(\mathrm{ab}^{\prime}\right)_{2}$ preparations were tested by applying anti$\mathrm{F}\left(\mathrm{ab}^{\prime}\right)_{2}$ and anti-Fc specific xenoantibodies. As expected, anti-F( $\left(\mathrm{ab}^{\prime}\right)_{2}$ antibodies gave positive reaction in all assays tested, while anti-Fc antibodies did not (Fig. 4). Thus, anti-pep and anti-cpep antibodies recognized each other in a specific manner, indicating their Id-anti-Id relationship.

Moreover, the specificity of anti-pep-anti-cpep antibody interaction was further demonstrated by homologous inhibition experiments using increasing quantity of soluble $\mathrm{F}\left(\mathrm{ab}^{\prime}\right)_{2}$ as inhibitor. The binding of anti-pep289-308 and anti-pep349-364 purified IgG to anti-cpep289-308 and anti-cpep349-364 $\mathrm{F}\left(\mathrm{ab}^{\prime}\right)_{2}$ inhibited the reaction in a dose-dependent manner with the higher rate at $65 \%$ and $67 \%$ respectively (Fig. 5A and B). Similarly, preincubation of anti-complementary peptide IgG, specific for cpep289-308 and cpep349-364 analogs, with soluble anti-pep289-308 and anti-pep349-364 F(ab') fragments, produced $52 \%$ and $48 \%$ inhibition of binding, respectively. 


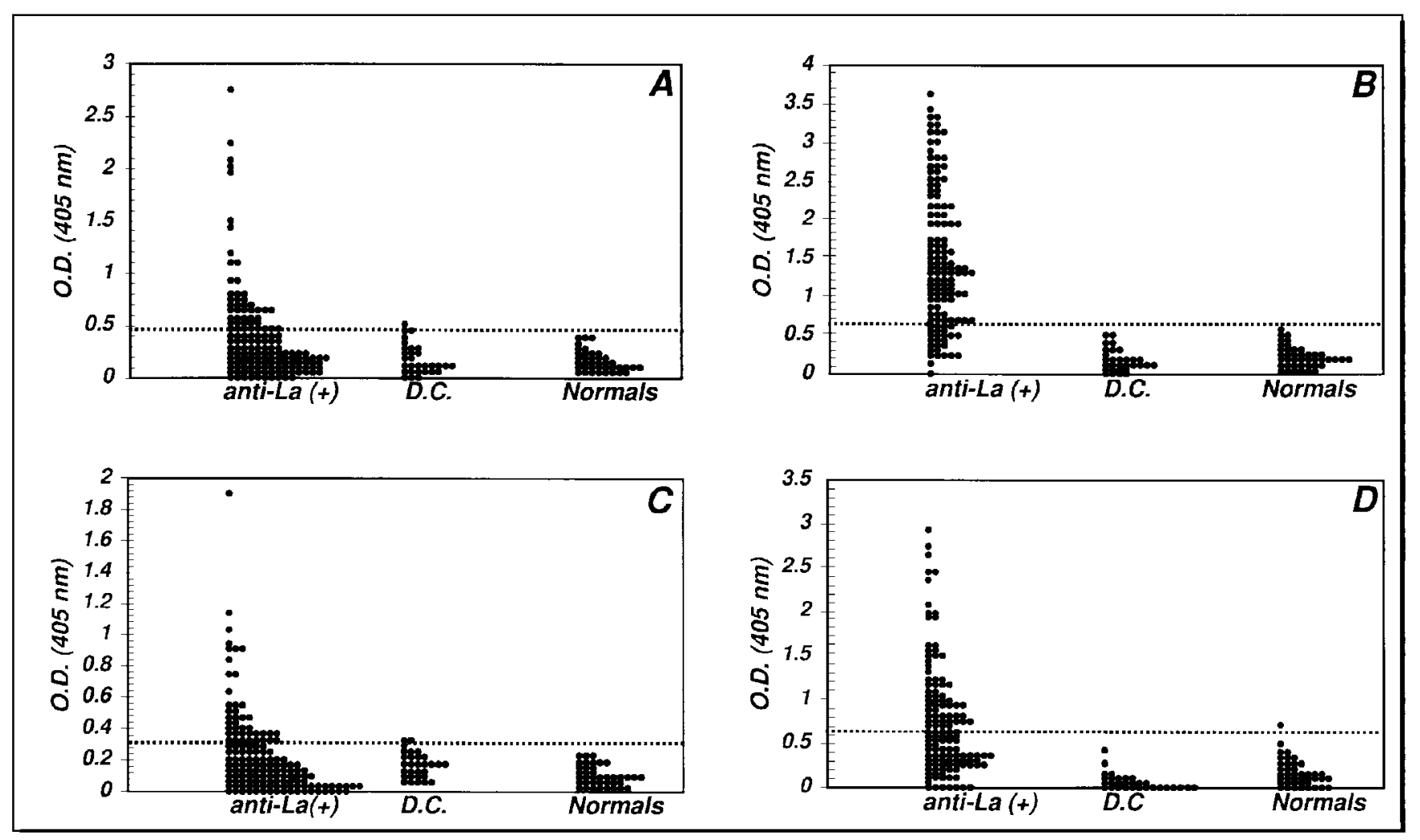

Fig. 3. Prevalence of antibodies against pep289-308 (A) pep349-364 (B) cpep289-308 (C) and cpep349-364 (D) synthetic peptides in human autoimmune sera, anti-La(+):sera positive for the anti-La/SSB antibodies by CIE, D.C.:disease controls; Normals:normal human sera.

\section{Assessment of Paratopic Binding}

To test whether anti-Id $\mathrm{F}\left(\mathrm{ab}^{\prime}\right)_{2}$ bound to a structure within or near the paratopic site of Id-bearing purified antibodies, the Id-anti-Id reaction was inhibited by preincubation of Id-bearing IgG with the corresponding reacting peptide.

In this regard, the binding of anti-pep289-308 and anti-pep349-364 IgG to their $\mathrm{F}\left(\mathrm{ab}^{\prime}\right)_{2}$ anti-idiotypic anti-cpep289-308 and anti-cpep349-364, was inhibited by $66 \%$ and $47 \%$ after incubation of IgG with the epitope analogs pep289-308 and pep349-364, respectively (Fig. 5C and D). The oligopeptide carrier $\mathrm{SOC}_{4}$, used as control peptide, showed no inhibitory effect to Id-anti-Id reaction (Fig. 5C and D). The reaction of immobilized anti-pep289-308 and antipep349-364 $\mathrm{F}\left(\mathrm{ab}^{\prime}\right)_{2}$ with soluble anti-cpep289-308 and anti-cpep349-364 IgG were also inhibited by $64 \%$ and $68 \%$, respectively, after incubation with the corresponding complementary peptides. Preincubation with the control peptide did not produce any inhibitory effect.

The inhibition of the binding of anti-cpep to anti-pep antibodies by the epitope peptide analogs, indicate that the anti-Id antibodies are reacting with idiotypes within or spatially close to the antigen combining site of anti-pep antibodies. In a similar manner, anti-pep antibodies bind the paratopic site of anti-cpep antibodies; their binding is abolished using as inhibitor the complementary peptide analog.

The spatial location of idiotypes of anti-pep antibodies were also sought by the ability of anticpep (anti-Id) IgG to inhibit the binding of Id-bearing anti-pep antibodies on the recombinant La/SSB autoantigen. The anti-La/SSB activity of purified anti-pep289-308 and anti-pep349-364 antibodies were specifically inhibited by $95 \%$ and $91 \%$, using as inhibitors anti-cpep289-308 and anti-cpep349-364 IgG, respectively (Fig. 6A and B).

\section{Evidence for Direct Association of La/SSB Epitopes With Their Complementary Peptides}

The ability of complementary peptides to recognize their counterparts was evaluated in two ways.

First, calculating the extent of inhibition caused if pep/cpep mixtures are tested against anti-pep IgG. Coincubation of biotinylated pep349-364 with cpep349-364 led to $76 \%$ inhibition of binding to anti-pep349-364 IgG (Fig. 7). Application of the same assay for the pair biotinylated pep289-308cpep289-308 caused $47 \%$ reduction of binding to anti-pep289-308. In both cases the use of control peptide instead of cpep analog did not affect the binding.

Second, using electrospray ionization mass spectrometry of the complexes formed by equimolar 


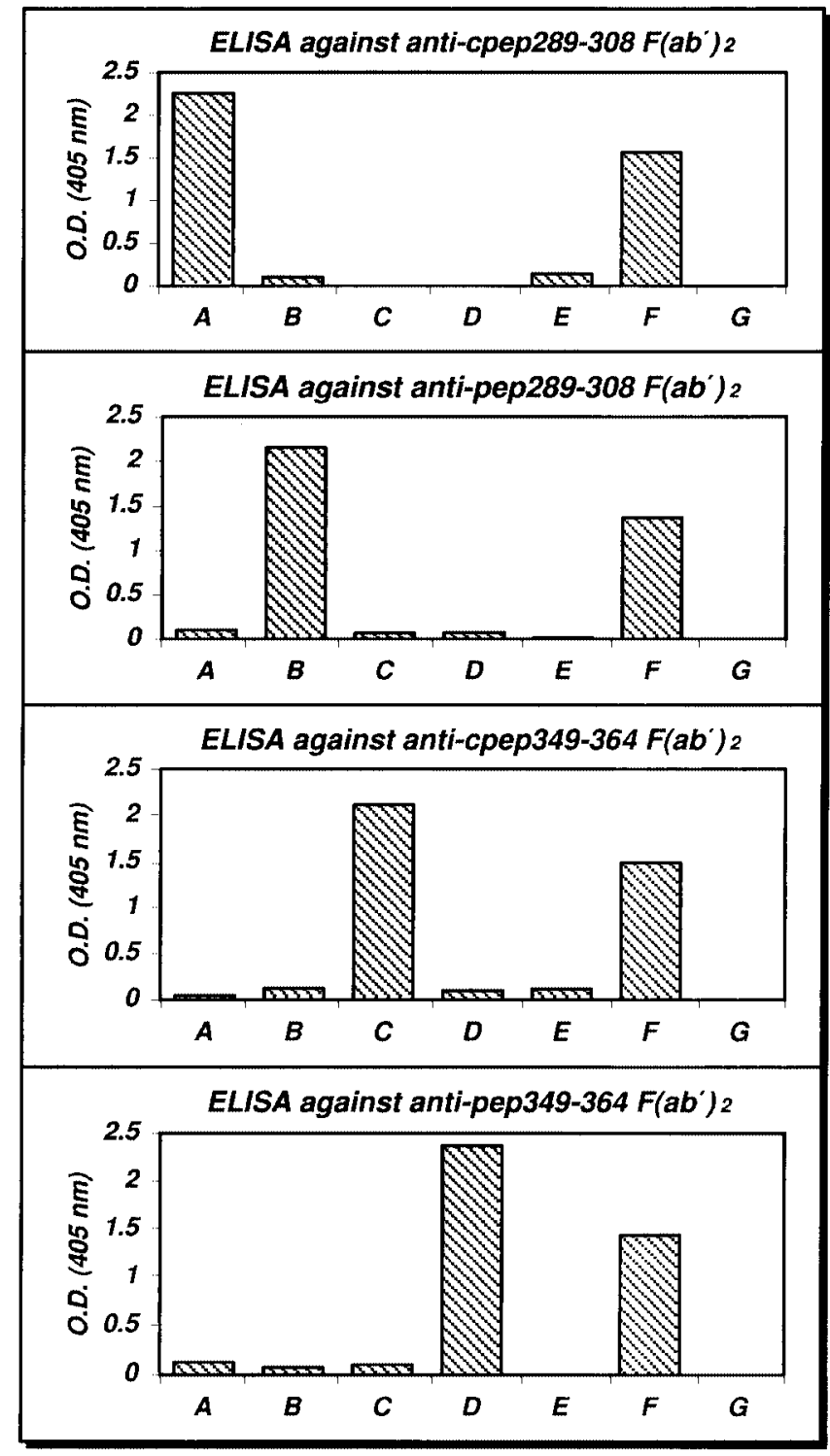

Fig. 4. Purified anti-complementary antibodies present anti-Id activity. The specificity of anti-Id activity of anticomplementary peptide antibodies was evaluated using purified anti-pep289-308 (A) anti-cpep289-308 (B) anti-pep349-364 (C) and anti-cpep349-364 (D) IgG, against isolated F(ab') $)_{2}$ fragments with different specificities. Columns E, F, and G represent the reactivity of normal IgG, anti-F( $\left(a b^{\prime}\right)_{2}$ and anti-Fc antibodies, respectively.

quantities of pep and cpep, respectively, a rather strong association was found between pep and their counterpeptides. More specifically, the calculated MW of the complexes pep289-308/cpep289-308 and pep349-364/cpep349-364 were 4801.5 and 3762.0, respectively. Their observed MW were $4804.87 \pm 6.9$ (molecular ions $[\mathrm{M}-4 \mathrm{H}]^{-4} / 4=$ 1198.82, $\left.[\mathrm{M}-6 \mathrm{H}]^{-6} / 6=798.93\right)$ and $3762 \pm 3.1$ (molecular ion $[\mathrm{M}-5 \mathrm{H}]^{-5} / 5=753.56$ ).

These results indicated that pep-cpep interaction has comparable affinity to that of pep-IgG association.
Idiotypes on IgG Against the Major B-Cell Epitope 349-364 a of La/SSB Are Shared in Common in Different Patients

Based on the observation that anti-complementary peptide antibodies target a structure near or within antigen combining site of anti-pep antibodies, we investigated whether this structure is common in different anti-pep IgG (public idiotype) or it is unique for each patient (private idiotype). Antipep349-364 specific IgG, purified from different patient sera (K.L., E.H., N.S., and T.K.), were all found to recognize anti-cpep349-364 $\mathrm{F}\left(\mathrm{ab}^{\prime}\right)_{2}$ from patient K.L. but not anti-pep349-364 $\mathrm{F}\left(\mathrm{ab}^{\prime}\right)_{2}$ isolated from the same patient serum or $F\left(a b^{\prime}\right)_{2}$ from normal IgG (Fig. 8).

These results indicate that anti-pep 349-364 IgG derived from different patients have idiotypes that resemble each other serologically (public idiotypes). These structures are most probably located within the paratopic site of the IgG.

\section{Blocking of Anti-Id Antibodies Recovers Hidden Anti-La/SSB Reactivity}

As previously demonstrated, anti-cpep (anti-Id) antibodies compete with the antigen for binding to the paratopic site of Id-bearing anti-pep antibodies. Anti-cpep349-364 antibodies were found capable of masking anti-La/SSB activity of anti-pep349-364 IgG; they almost completely inhibited the binding of the latter to La/SSB antigen. This phenomenon could be involved in the serologic detection of antiLa/SSB antibodies, negatively affecting the sensitivity of the assay.

In this regard, a procedure to overcome this anti-cpep interference in La/SSB detection was developed (Figs. 9A-D). Sera were heated at $55^{\circ} \mathrm{C}$ for the dissociation of Id-anti-Id complexes. Subsequently cpep349-364 (in $\mathrm{SOC}_{2}$ form) was added as anti-Id blocking agent (Fig. 9A and B). At this temperature, IgG remains stable without major denaturation effects (39). Afterward, the mixture was submitted to slow cooling $\left(55^{\circ} \mathrm{C} \rightarrow 25^{\circ} \mathrm{C}\right.$ in $3 \mathrm{hr}$ ) and a new equilibrium was established with the participation of cpep as anti-Id antibody binder and the subsequent release of a portion of Id (antipep) antibodies (Fig. 9C). To counterbalance the expected higher affinity of Id-anti-Id interaction, cpep was used in molar excess. The procedure was followed by an anti-pep349-364 ELISA as described (Fig. 9D). The efficiency of this assay, was tested in two systems:

1. One patient became negative for anti-La/SSB antibodies in CIE and ELISA over a period of 7 months. After heat and cpep349-364 treatment the anti-La activity of the new serum was restored (Fig. 9E). The same assay using a control peptide had no positive effect in anti-La/SSB reactivity. The incubation with cpep349-364 without prior heating of the sample was also not sufficient to unblock anti-La/SSB antibodies (Fig. 9E). 


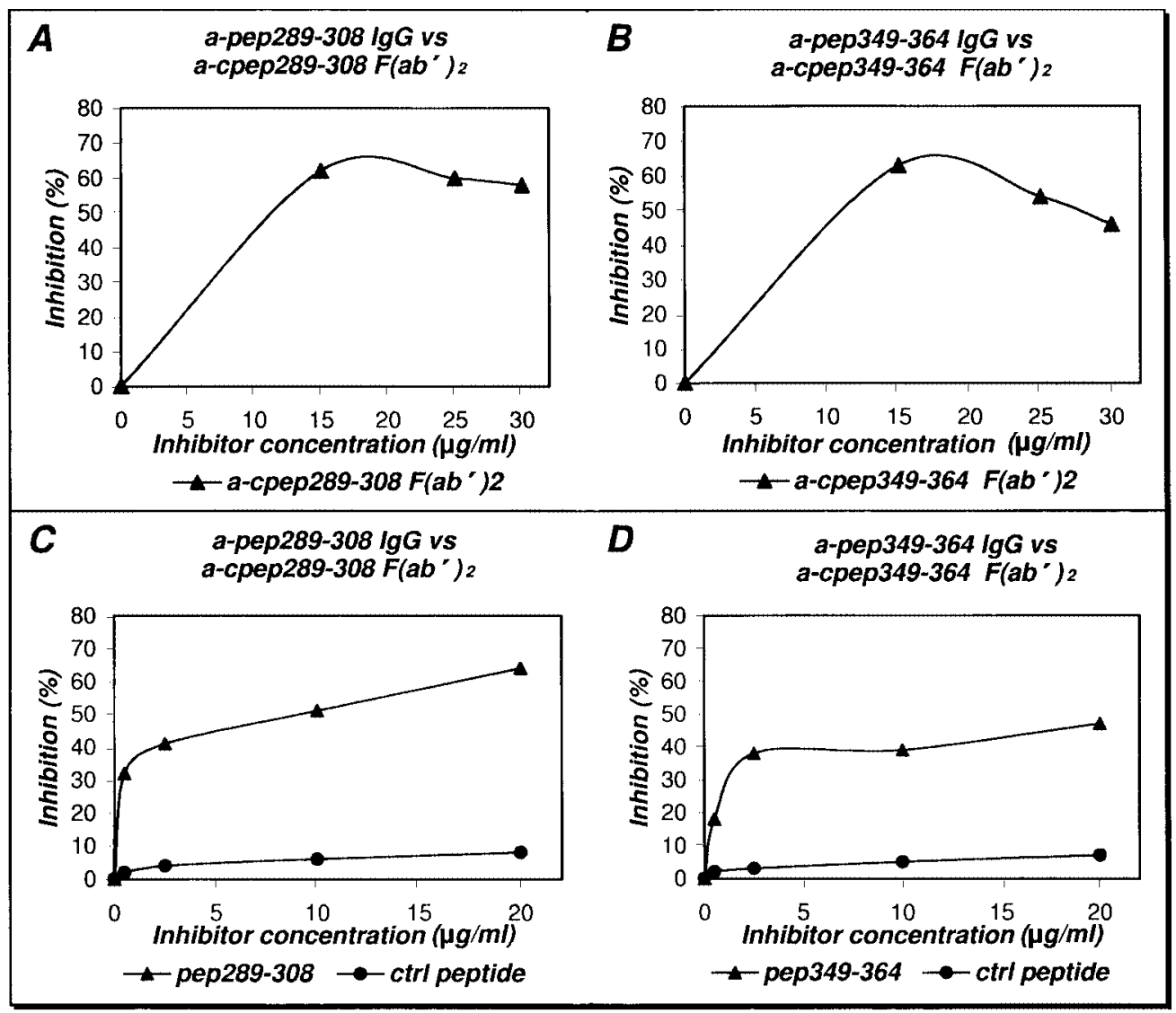

Fig. 5. Inhibition assays. (A and B): Homologous inhibition of anti-Id antibodies. A: Soluble anti-cpep289-308 F(ab') ${ }_{2}$ inhibited the binding by $65 \%$ while anti-cpep349-364 $\mathrm{F}\left(\mathrm{ab}^{\prime}\right)_{2}$ produced $67 \%$ inhibition. (C and D): Competitive inhibition of binding of anti-Id antibodies to antigen combining site. Pep289-308 inhibited the binding of anti-pep289-308 IgG to the anti-cpep289-308 $\mathrm{F}\left(\mathrm{ab}^{\prime}\right)_{2}$ by $68 \%$ (C) and pep349-364 inhibited anti-pep349-364 IgG-anti-cpep349-364 $\mathrm{F}\left(\mathrm{ab}^{\prime}\right)_{2}$ reaction by $47 \%$ (D).

2. Application of a human serum with high levels of anti-pep349-364 and anti-cpep349-364 antibodies to peptide-immunoaffinity columns yielded $6.01 \mathrm{mg}$ of anti-pep349-364 and $0.20 \mathrm{mg}$ of anti- cpep349364 antibodies (Figs. 9F-I). The fraction which was not retained by the columns, passed through the columns for second time, after concentration in the initial volume, and yielded no

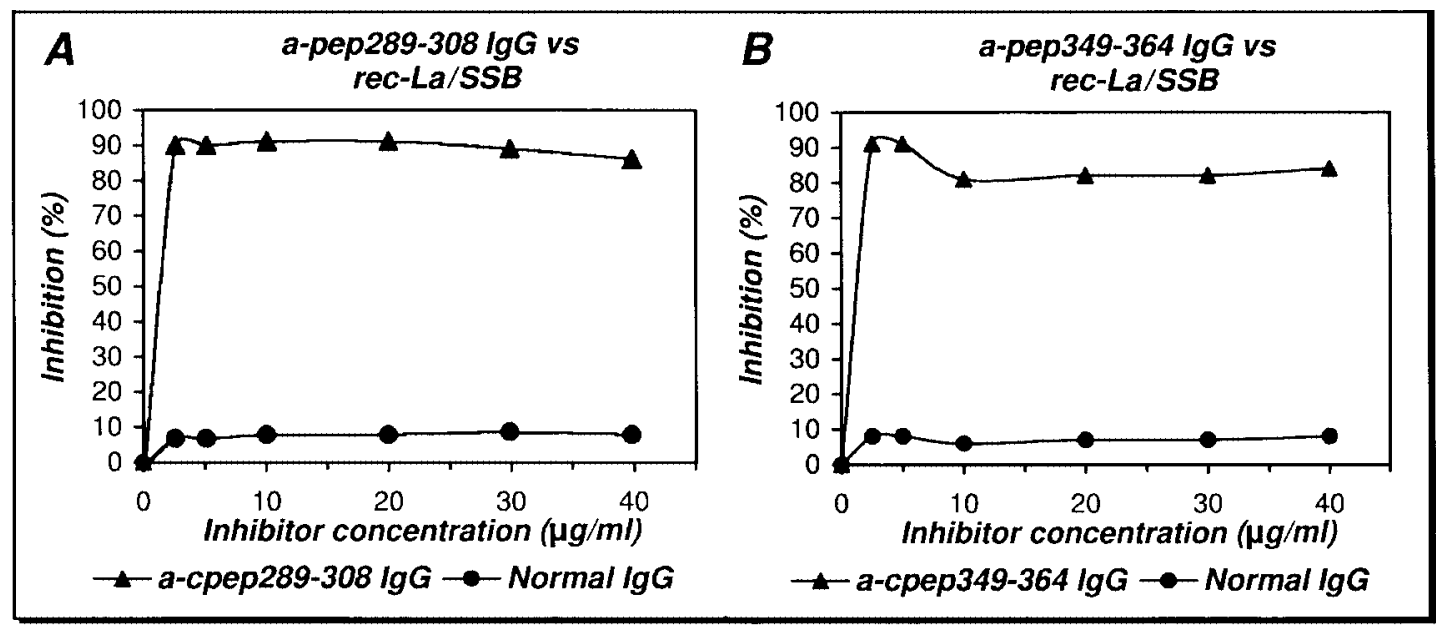

Fig. 6. Inhibition of antibody binding to recombinant La/SSB by anti-idiotypic antibodies. (A) Anti-pep289-308 IgG inhibited the binding of anti-pep289-308 IgGon recombinant La/SSB by 95\%. (B) Anti cpep349-364 IgG inhibited the binding of antipep349-364 IgG to recombinant La/SSB by $91 \%$. 


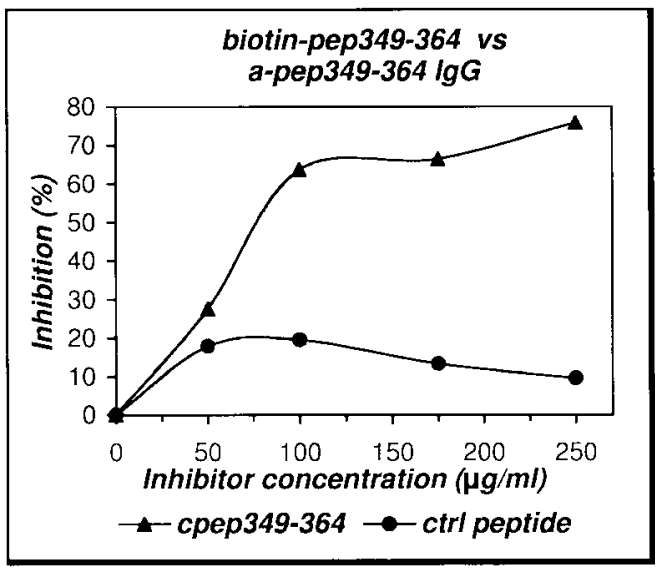

Fig. 7. Inhibition of paratope-epitope binding by senseantisense peptide interactions. The inhibitor cpep349-364 reduced the binding of biotinylated pep349-364 to anti-pep $349-364$ IgG by $76 \%$. Ctrl peptide:control peptide.

significant amount of antibodies $(0.77 \mathrm{mg}$ of antipep349-364) (Fig. 9F-II). The same fraction was submitted to thermal treatment with the addition of $0.9 \mathrm{mg}$ of cpep349-364, dialyzed overnight against PBS to remove cpep excess, and passed through the immunoaffinity columns for third time. Elution of the columns yielded $3.90 \mathrm{mg}$ of anti-pep349-364 IgG (Fig. 9F-III), a finding that confirms the previous results and suggests that a significant amount of anti-pep349-364 can be released using the previously described procedure.

Masked Anti-La/SSB Antibodies are Detected in Anti-Ro/SSA(+), Anti-La/SSB(-) Human Autoimmune Sera

To identify the prevalence of masked anti-La/SSB antibodies in anti-La/SSB negative autoimmune sera,

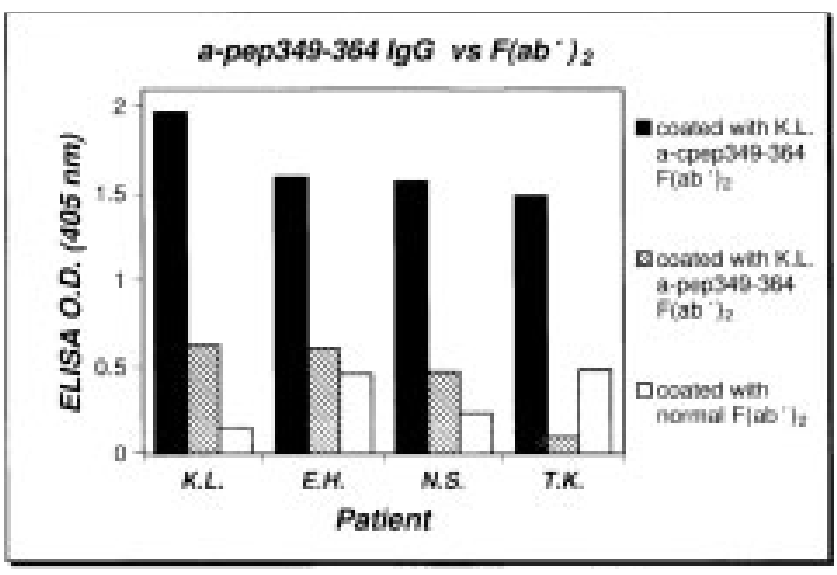

Fig. 8. Identification of a cross-reactive idiotype. A common Id is recognized by anti-cpep349-364 $\mathrm{F}\left(\mathrm{ab}^{\prime}\right)_{2}$ on anti-pep349-364 IgG derived from different patients. Sera from different patients reacted with the anti-cpep349-364 $\mathrm{F}\left(\mathrm{ab}^{\prime}\right)_{2}$ of the same patient (K.L.). These sera did not react with either pep349-364 IgG or normal $\mathrm{F}\left(a b^{\prime}\right)_{2}$. we applied the heat and cpep treatment method to 44 ANA(+)/anti-Ro(+) autoimmune sera without anti$\mathrm{La}$ /SSB antibodies in CIE. Fourteen sera from SLE patients with anti-Sm and/or anti-UIRNP antibodies were used as controls. Ninety four percent of pSS sera and $80 \%$ of SLE sera were found also negative in anti-pep349-364 ELISA. Using the described method, all anti-Ro positive autoimmune sera gave also positive anti-pep349-364 reaction in ELISA whereas normal sera and sera with anti Sm/UIRNP antibodies remained negative (Fig. 10 and data not shown). This positive reaction cannot be attributed to thermal treatment of sera, because heat alone without the addition of cpep349-364 peptide in sera does not affect the anti-pep349-364 ELISA. Clinical evaluation disclosed no differences between patients with seropositive anti-La/SSB and patients with hidden anti-La/SSB antibodies.

\section{Discussion}

Anti-idiotypic and anti-clonotypic antibodies to autoantibodies and autoreactive T-cells, respectively, represent theoretically the ideal treatment of autoimmune diseases because they can specifically affect the harmful autoreactive cells without compromising the ability of the immune system to respond to foreign antigens. Previous studies in systemic autoimmune diseases have shown that anti-idiotypic antibodies to intracellular autoantigens may play a role in regulation of the autoimmune response (40).

In the present report, we used the antisensecomplementary peptide approach in an operational sense to derive peptides capable of detecting anti-idiotypic antibodies to La/SSB major B- and T-cell epitopes. The two synthesized complementary peptides cpep289-308 and cpep349-364 were found to possess inverted hydrophobicity profiles compared with the corresponding La/SSB epitopes pep289-308 and pep349-364 (sense peptides), that is consistent with the molecular recognition theory (13-15). This observation reflects most likely one more degree of degeneration of the genetic code; the second position of codons is strongly correlated with the hydrophobicity of amino acids (41). All codons with uracil in second position translate to hydrophobic amino acids, whereas adenine in the same position results in hydrophilic amino acids. Most codons with cytosine or guanine in second position correspond to intermediate hydrophilicity amino acids, according to the GES scale $(38,41)$. Because uracil pairs with adenine and cytosine with guanine, it is not surprising that sense and antisense peptides possess inverted hydrophilicity profiles. On a biochemical basis, it has been proposed that the hydropathic complementarity may lead to strong interactions between peptides (42), which has been confirmed by analytical methods (43-45). In the present report, the interaction between the epitope analogs of $\mathrm{La}$ /SSB and their complementary peptides has been 


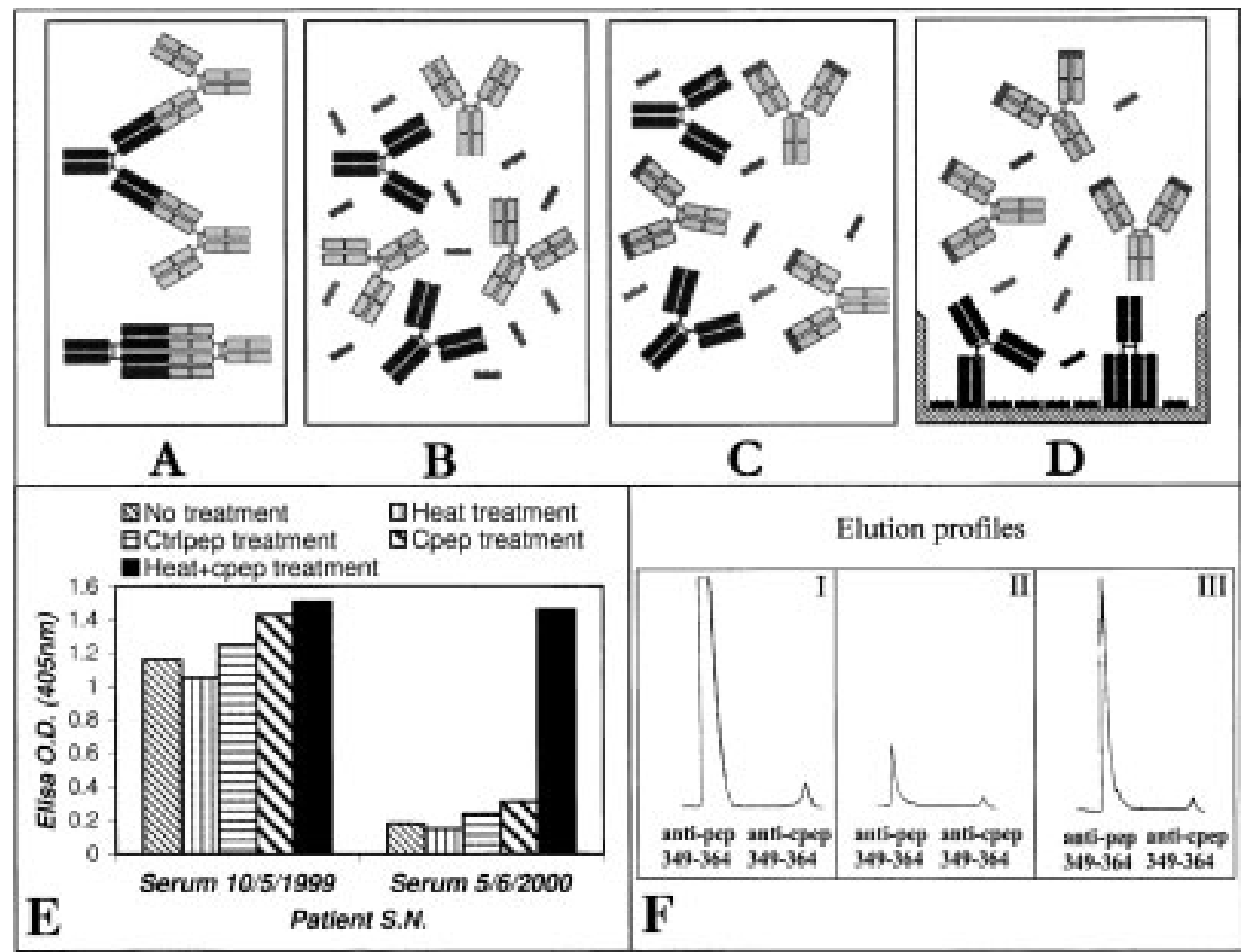

Fig. 9. Recovery of masked anti-La/SSB reactivity by specific blocking of anti-Id antibodies. In some sera anti-Id antibodies (shown in gray) bind and mask anti-La/SSB antibodies (idiotypes) (shown in black) (A) Heating at $55^{\circ} \mathrm{C}$ dissociates Id-anti-Id complexes and cpep349-364 is added (B) Slow-cooling to $25^{\circ} \mathrm{C}$ allows cpep to react with a portion of anti-Id antibodies (C) The unmasked Id antibodies can be detected by a pep349-364 ELISA (D) This assay was utilized (a) For the detection of hidden anti$\mathrm{La}$ /SSB reactivity in a patient serum (E). This patient was initially positive for antibodies to pep349-364 (10/5/1999). Seven months later (5/6/2000) antibodies to pep349-364 were not detected by the conventional method. Application of the heat and cpep treatment assay restored anti-pep349-364 reactivity. (b) For isolation of masked anti-pep349-364 antibodies (F). The heat and cpep technique applied to the IgG fraction of a human serum, which was not retained by anti-pep349-364 immunoaffinity column (I-III) as described in the results section. In panel III, $3.9 \mathrm{mg}$ of hidden-anti-pep349-364 antibodies was isolated.

demonstrated using two different experimental procedures: first, by the detection of the epitope/complementary peptide complex with mass spectroscopy, and second by a specific inhibition assay, where coincubation of cpep349-364 with biotinylated pep349-364 inhibited the binding of the latter to anti-pep349-364 IgG, suggesting that a direct cpeppep interaction in liquid phase occurs.

The most striking finding in this study was that sera from patients with pSS and SLE contain anticpep antibodies that possess anti-idiotypic activity and compete with pep or La/SSB antigen for binding to the paratopic site of Id-bearing anti-pep antibodies. These anti-Id antibodies are likely to belong to antigen inhibitable (Ab2 $\beta$ or "internal image") anti-idiotypes according to Jerne's classification, which most likely recognize public (common) idiotypes (46). Indeed, purified anti-pep349-364 antibodies from different sera were found to possess cross-reactive idiotypes; they are all recognized by a unique anti-cpep349-364 $\mathrm{F}\left(\mathrm{ab}^{\prime}\right)_{2}$ fragment. The possibility of rheumatoid factor interference in this assay must be excluded; anti-pep 349-364 IgG reacted specifically with anti-cpep349-364 and not with IgG of other specificities or normal immunoglobulin. Furthermore, in all Id-anti-Id assays, $\mathrm{F}\left(\mathrm{ab}^{\prime}\right)_{2}$ fragments have been utilized.

In favor of these findings are recent immunization experiments, where BALB/c mice immunized with either pep or cpep developed antibodies to pep or cpep, following by the production of antibodies to their counterparts cpep and pep respectively (data not presented).

On clinical and diagnostic grounds, the most prominent finding arising from this work is the ability of the complementary peptide to unmask the anti$\mathrm{La} / \mathrm{SSB}$ response. It is of particular interest that nearly all anti-Ro/SSA positive-anti-La/SSB negative sera tested possessed masked antibodies to the major epitope 349-364aa of La/SSB. These antibodies were released and detected after a specific treatment of the sera, aiming first to dissociate Id-anti-Id-immune 


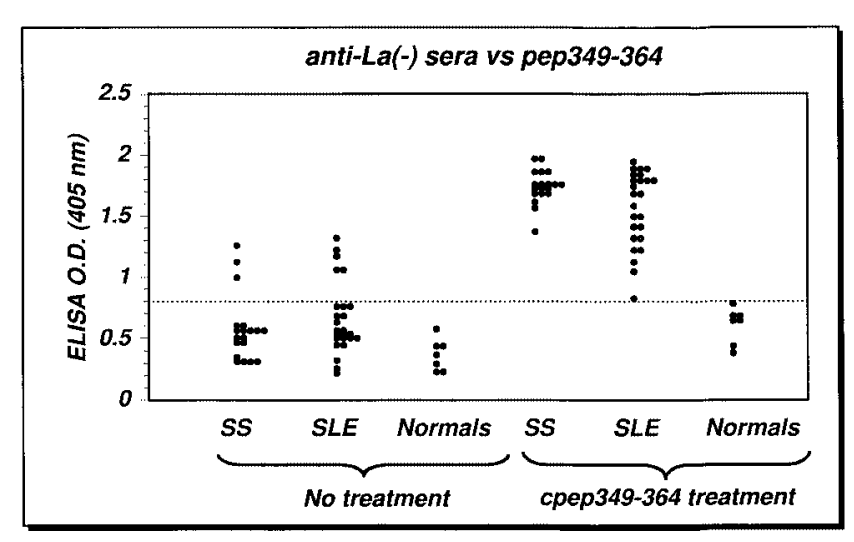

Fig. 10. Prevalence of antibodies against La/SSB major B-cell epitope 349-364 in anti-La/SSB negative autoimmune sera before and after heat and cpep349-364 treatment. The dotted line denotes the cutoff point set by the mean optical density of the normal sera plus $3 \mathrm{SD}$.

complexes by heating and block, afterward, the antiidiotypic antibodies using complementary peptides. Anti-Ro/SSA positive-anti-La/SSB precipitin negative sera represent a stable serologic subset among patients with pSS (47). These sera are all negative for antibodies against the LaL2/3 fragment of $\mathrm{La} / \mathrm{SSB}$, and although they recognize the full-length recombinant protein. In contrast, almost all $(\mathbf{9 2} \%)$ $\mathrm{La} / \mathrm{SSB}$ precipitin positive sera react with both the aforementioned region, as well as the full-length La/SSB protein (48). As LaL2/3 fragment corresponds to the 346-408 part of La/SSB sequence containing the 349-364aa major B-cell epitope, it seems highly likely that anti-idiotypic antibodies are capable, in some cases, of efficiently blocking the La/SSB recognition by anti-pep349-364 antibodies, halting the spreading of the autoimmune response and affecting the serologic profile of the patients. The genetic associations of La/SSB precipitin negative sera have also been studied. Patients without La/SSB precipitin antibodies carried alleles of DR2-DQ1 haplotype, whereas La/SSB precipitin positive patients expressed DR3/DQ2 HLA (4). This is in agreement with our recent observation that antipep349-364 correlate with the DR3 haplotype (49). Taken together, these data support the view that the development of anti-La/SSB blocking anti-Id antibodies is probably dependent on specific genetic background and seems to be capable of affecting the serologic profiles of patients. Therefore, cpep349364 complementary peptide might prove useful for both development of sensitive assays for anti$\mathrm{La} / \mathrm{SSB}$ detection and regulation of autoimmune response against La/SSB $(50,51)$. Taking into consideration the high specificity and sensitivity of anti-pep349-364 ELISA $(6,24)$, the incorporation of cpep349-364 treatment to this assay will provide beneficial properties for the detection of anti-La/SSB antibodies and advantages over the other conventional methods.
The presence of both anti-pep and anti-cpep antibodies in the same sera, raises the question whether the anti-cpep response is the initiation agent for the formation of anti-pep antibodies or it is a consequence of them. From this point of view, three additional explanations for the origin of anticpep antibodies should be considered. First, anticpep antibodies could be generated as a response to a complementary peptide sequence bearing protein produced by reverse strand transcription and translation. Antisense translation has been recently demonstrated as an alternative mechanism of gene expression in virus-infected, tumor, or normal human cells $(52,53)$. This mechanism could be implicated only in the production of cpep349-364 peptide (the cpep289-308 originally possessed three stop codons). Second, antibodies to complementary peptides could occur by molecular mimicry with a host protein or an infectious agent product that resembles cpep structures (54). Alternatively, anticpep antibodies may arise as response to a self or most likely nonself protein with La/SSB binding properties (55). In this case, anti-ligand-protein antibodies could induce the formation of antiidiotypic antibodies recognizing $\mathrm{La}$ /SSB antigen (12). Related to this mechanism could be the observation that the C-terminal region of La/SSB antigen (where the two epitopes are residing), but not its RNA binding domain, enhances viral translation/replication (56) as well as the reported specificity of poliovirus $3 C^{\text {pro }}$ protease for $\mathrm{La} / \mathrm{SSB} \mathrm{Q}^{358}$ $\mathrm{G}^{359}$ bond (57).

In conclusion, our study demonstrated that virtually all anti-Ro/SSA positive autoimmune sera possess also anti-La/SSB antibodies, but in some cases the latter are efficiently masked by a specific anti-idiotypic response, abrogating their ability to bind the target epitope. These anti-idiotypic antibodies can be identified and isolated using complementary peptides to major epitopes of La/SSB. Over the above, a new methodology has been developed to restore the hidden anti-La/SSB reactivity, providing new advantages for the detection of anti-La/SSB autoantibodies. The possibility that anti-cpep antibodies can serve as a triggering factor for antiLa/SSB autoantibody formation is currently under investigation in our laboratory.

\section{Acknowledgment}

This work was supported by a grant (PENED 5065) from the Greek Secretariat of Research and Technology.

\section{References}

1. Pruijn GJ, Slobbe R. Van-Venrooij WJ. (1990) Structure and function of La and Ro RNPs. Mol. Biol. Rep. 14: 43-48.

2. Fatenejad S, Mamula M, Craft J. (1993) Role of intermolecular/intrastructural B- and T-cell determinants in the diversification of autoantibodies to ribonucleoprotein particles. Proc. Natl. Acad. Sci. U.S.A. 90: 12010-12014. 
3. Gordon TP, Greer M, Reynolds P, Guidolin A, McNeilage LJ. (1991) Estimation of amounts of anti-La (SS-B) antibody directed against immunodominant epitopes of the La(SS-B) autoantigen. Clin. Exp. Immunol. 85: 402-406.

4. McCluskey J, Farris AD, Keech CL, et al. (1998) Determinant spreading: lessons from animal models and human disease. Immunol. Rev. 164: 209-229.

5. Routsias JG, Tzioufas AG, Sakarellos-Daitsiotis M, Sakarellos C, Moutsopoulos HM. (1996) Epitope mapping of the Ro/ SSA60KD autoantigen reveals disease-specific antibodybinding profiles. Eur. J. Clin. Invest. 26: 514-521.

6. Tzioufas AG, Yiannaki E, Sakarellos DM, Routsias JG, Sakarellos C, Moutsopoulos HM. (1997) Fine specificity of autoantibodies to La/SSB: epitope mapping, and characterization. Clin. Exp. Immunol. 108: 191-198.

7. Moutspoulos NM, Routsias JG, Vlachoyiannopoulos PG, Tzioufas AG, Moutsopoulos HM. (2000) B-Cell Epitopes of Intracellular Autoantigens: Myth and Reality. Mol. Med. 6: $141-151$.

8. Yiannaki E, Vlachoyiannopoulos PG, Manousakis MN, et al. (2000) Study of antibody and T-cell responses in rabbits immunized with synthetic human B cell epitope analogs of La (SSB) autoantigen. Clin. Exp. Immunol. 121: 1-7.

9. Reynolds P, Gordon TP, Purcell AW, Jackson DC, McCluskey J. (1996) Hierarchical self-tolerance to $T$ cell determinants within the ubiquitous nuclear self-antigen La (SS-B) permits induction of systemic autoimmunity in normal mice. J. Exp. Med. 184: 1857-1870.

10. Farris AD, Brown L, Reynolds P, et al. (1999) Induction of autoimmunity by multivalent immunodominant and subdominant $\mathrm{T}$ cell determinants of La (SS-B). J. Immunol. 162: 3079-3087.

11. Schluter SF, Wang E, Winfield JB, Yocum DE, Marchalonis JJ. (1995) Autoregulation of TCR V region epitopes in autoimmune disease. Adv Exp Med Biol 383: 231-236.

12. Kohler H, Kaveri S, Kieber-Emmons T, Morrow WJ, Muller S, Raychaudhuri S. (1989) Idiotypic networks and nature of molecular mimicry: an overview. Methods Enzymol. 178: 3-35.

13. Blalock JE, Bost KL. (1986) Binding of peptides that are specified by complementary RNAs. Biochem. J. 234: 679-683.

14. Bost KL, Blalock JE. (1989) Preparation and use of complementary peptides. Methods Enzymol. 168: 16-28.

15. Blalock JE, Whitaker JN, Benveniste EN, Bost KL. (1989) Use of peptides encoded by complementary RNA for generating anti-idiotypic antibodies of predefined specificity. Methods Enzymol. 178: 63-74.

16. Smith LR, Bost KL, Blalock JE. (1987) Generation of idiotypic and anti-idiotypic antibodies by immunization with peptides encoded by complementary RNA: a possible molecular basis for the network theory. J. Immunol. 138: 7-9.

17. Araga S, LeBoeuf RD, Blalock JE. (1993) Prevention of experimental autoimmune myasthenia gravis by manipulation of the immune network with a complementary peptide for the acetylcholine receptor. Proc. Natl. Acad. Sci. U.S.A. 90: 874-875.

18. Araga S, Kishimoto M, Doi S and Nakashima K (1999) A complementary peptide vaccine that induces $\mathrm{T}$ cell anergy and prevents experimental allergic neuritis in Lewis rats. J. Immunol. 163: 476-482.

19. Araga S, Xu L, Nakashima K, Villain M, Blalock JE. (2000) A peptide vaccine that prevents experimental autoimmune myasthenia gravis by specifically blocking $\mathrm{T}$ cell help. FASEB $\mathrm{J}$. 14: 185-196.

20. Mulchahey JJ, Neill JD, Dion LD, Bost KL, Blalock JE. (1986) Antibodies to the binding site of the receptor for luteinizing hormone-releasing hormone (LHRH): generation with a synthetic decapeptide encoded by an RNA complementary to LHRH mRNA. Proc. Natl. Acad. Sci. U.S.A. 83: 9714-9718.

21. Borovsky D, Powell CA, Nayar JK, Blalock JE, Hayes TK. (1994) Characterization and localization of mosquito-gut receptors for trypsin modulating oostatic factor using a complementary peptide and immunocytochemistry. FASEB $J$. 8: $350-355$.
22. Martins VR, Graner E, Garcia AJ, et al. (1997) Complementary hydropathy identifies a cellular prion protein receptor. Nat. Med. 3: 1376-1382.

23. Herrera VL, Ruiz-Opazo N. (2001) Identification of a novel Vl-type AVP receptor based on the molecular recognition theory. Mol. Med. 7: 499-506.

24. Yiannaki EE, Tzioufas AG, Bachmann M, et al. (1998) The value of synthetic linear epitope analogs of $\mathrm{La} / \mathrm{SSB}$ for the detection of autoantibodies to La/SSB; specificity, sensitivity and comparison of methods. Clin. Exp. Immunol. 112: 152-158.

25. Vitali C, Bombardieri S, Moutsopoulos HM, et al. (1993) Preliminary criteria for the classification of Sjogren's syndrome. Results of a prospective concerted action supported by the European Community. Arthritis Rheum. 36: 340-347.

26. Tan EM, Cohen AS, Fries JF, et al. (1982) The 1982 revised criteria for the classification of systemic lupus erythematosus. Arthritis Rheum. 25: 1271-1277.

27. Bodanszky M. (1990) Principles of Peptide Synthesis. New York: Springer-Verlag.

28. Sakarellos-Daitsiotis $M$, Tsikaris V, Vlachoyiannopoulos PG, Tzioufas AG, Moutsopoulos HM, Sakarellos C. (1999) A helicoids-type sequential oligopeptide carrier (SOCn) for multiple anchoring of antigenic/immunogenic peptides. Method-A Companion to Methods in Enzymology 133: 19.

29. Sakarellos-Daitsiotis M, Tsikaris V, Sakarellos C, Vlachoyiannopoulos PG, Tzioufas AG, Moutsopoulos HM. (2000) A new helicoid-type sequential oligopeptide carrier (SOCn) for developing potent antigens and immunogens. Vaccine 18: 302-310.

30. Troster H, Metzger TE, Semsei I, et al. (1994) One gene, two transcripts: isolation of an alternative transcript encoding for the autoantigen La/SS-B from a cDNA library of a patient with primary Sjogrens' syndrome. J. Exp. Med. 180: 2059-2067.

31. Stefano JE. (1984) Purified lupus antigen La recognizes an oligouridylate stretch common to the 3' termini of RNA polymerase III transcripts. Cell 36: 145-154.

32. Rousseaux J, Rousseaux-Prevost R, Bazin H. (1983) Optimal contitions for the preparation of $F a b$ and $F\left(a b^{\prime}\right)_{2}$ fragments from monoclonal IgG of different rat IgG subclasses. J. Immunol. Methods 64: 141-146.

33. Sasso EH, Silverman GJ, Mannik M. (1991) Human IgA and $\operatorname{IgG} \mathrm{F}\left(\mathrm{ab}^{\prime}\right) 2$ that bind to staphylococcal protein A belong to the VHIII subgroup. J. Immunol. 147: 1877-1883.

34. Lamoyi E, Nisonoff A. (1983) Preparation of $F\left(a b^{\prime}\right) 2$ fragments from mouse IgG of various subclasses. J. Immunol. Methods 56: 235-243.

35. Engvall E, Perlman P. (1971) Enzyme-linked immunosorbent assay (ELISA) quantitative assay of immunoglobulin G. Immunochemistry 8: 871-874.

36. Blalock JE, Smith EM. (1984) Hydropathic anticomplementarity of amino acids based on the genetic code. Biochem. Biophys. Res. Commun. 121: 203-207.

37. Fauchere JL, Charton M, Kier LB, Verloop A, Pliska V. (1988) Amino acid side chain parameters for correlation studies in biology and pharmacology. Int. J. Pept. Protein Res. 32: 269-278.

38. Engelman DM, Steitz TA, Goldman A. (1986) Identifying nonpolar transbilayer helices in amino acid sequences of membrane proteins. Annu. Rev. Biophys. Biophys. Chem. 15: $321-353$.

39. Lopez AL, Pineda E, Garakian A, Cherry JD. (1998) Effect of heat inactivation of serum on Bordetella pertussis antibody determination by enzyme-linked immunosorbent assay. Diagn. Microbiol. Infect. Dis. 30: 21-24.

40. Zhang W, Reichlin M. (1996) Some autoantibodies to Ro/SS$\mathrm{A}$ and La/SS-B are antiidiotypes to anti-double-stranded DNA. Arthritis Rheum. 39: 522-531.

41. Tolstrup N, Toftgard J, Engelbrecht J, Brunak S. (1994) Neural network model of the genetic code is strongly correlated to the GES scale of amino acid transfer free energies. J. Mol. Biol. 243: 816-820.

42. Markus G, Tritsch GL, Parthasarathy R. (1989) A model for hydropathy-based peptide interactions. Arch. Biochem. Biophys. 272: 433-439. 
43. Shai Y, Flashner M, Chaiken IM. (1987) Anti-sense peptide recognition of sense peptides: direct quantitative characterization with the ribonuclease S-peptide system using analytical high-performance affinity chromatography. Biochemistry 26: 669-675.

44. Fassina G, Roller PP, Olson AD, Thorgeirsson SS, Omichinski JG. (1989) Recognition properties of peptides hydropathically complementary to residues $356-375$ of the c-raf protein. J. Biol. Chem. 264: 11252-11257.

45. Loo JA, Holsworth DD, Root-Bernstein RS. (1994) Use of electrospray ionization mass spectrometry to probe antisense peptide interactions. Biol. Mass. Spectrom. 23: 6-12.

46. Jerne NK, Roland J, Cazenave PA. (1982) Recurrent idiotopes and internal images. EMBO J. 1: 243-247.

47. Beer RG, Rischmueller $M$, Coates T, et al. (1996) Nonprecipitating anti-La(SS-B) autoantibodies in primary Sjogren's syndrome. Clin. Immunol. Immunopathol. 79: 314318.

48. Gordon T, Mavrangelos C, McCluskey J. (1992) Restricted epitope recognition by precipitin-negative anti-La/SS-B-positive sera. Arthritis Rheum. 35: 663-666.

49. Tzioufas AG, Wassmuth R, Dafni UG, et al. (2002) Clinical, immunologic and immunogenetic aspects of autoantibody production against to Ro/SSA, La/SSB and their linear epitopes in primary sjogren's syndrome (Pss): a European Multicenter Study. Ann. Rheum. Dis. 61: 398-404.
50. Zanetti M, Rogers J, Katz DH. (1988) Perturbation of the autoimmune network. I. Immunization with anti-idiotypic antibodies prior to challenge with antigen induces quantitative variations in the autoantibody response. Autoimmunity 1: 23-36.

51. Zanetti M, Glotz D, and Rogers J. (1986) Perturbation of the autoimmune network. II. Immunization with isologous idiotype induces auto-anti-idiotypic antibodies and suppresses the autoantibody response elicited by antigen: a serologic and cellular analysis. J. Immunol. 137: 3140-3146.

52. Vanhee BC, Vaquero C. (1998) Do natural antisense transcripts make sense in eukaryotes? Gene 211: 1-9.

53. Van den Eydde BJGB, Probst-Kepper M, Michaux L, et al. (2000) A new antigen recognized by cytosolic T lymphocytes on a human kidney tumor results from reverse strand transcription. J. Exp. Med. 190: 1793-1799.

54. Plotz P H (1983) Autoantibodies are anti-idiotype antibodies to antiviral antibodies. Lancet 2: 824-826.

55. Guercio P, Zanetti M. (1987) The CD4 molecule, the human immunodeficiency virus and anti-idiotypic antibodies. Immunol. Today 8: 204-205.

56. Craig AW, Svitkin YV, Lee HS, Belsham GJ, Sonenberg N. (1997) The La autoantigen contains a dimerization domain that is essential for enhancing translation. Mol. Cell Biol. 17: 163-169.

57. Shiroki K, Isoyama T, Kuge S, Ishii T, Ohmi S, et al. (1999) Intracellular redistribution of truncated La protein produced by poliovirus 3Cpro-mediated cleavage. J. Virol. 73: 2193-2200. 